\title{
28
}

\section{Established and recent policy arrangements for river management in The Netherlands: an analysis of discourses}

\section{Irene Immink $k^{\#}$}

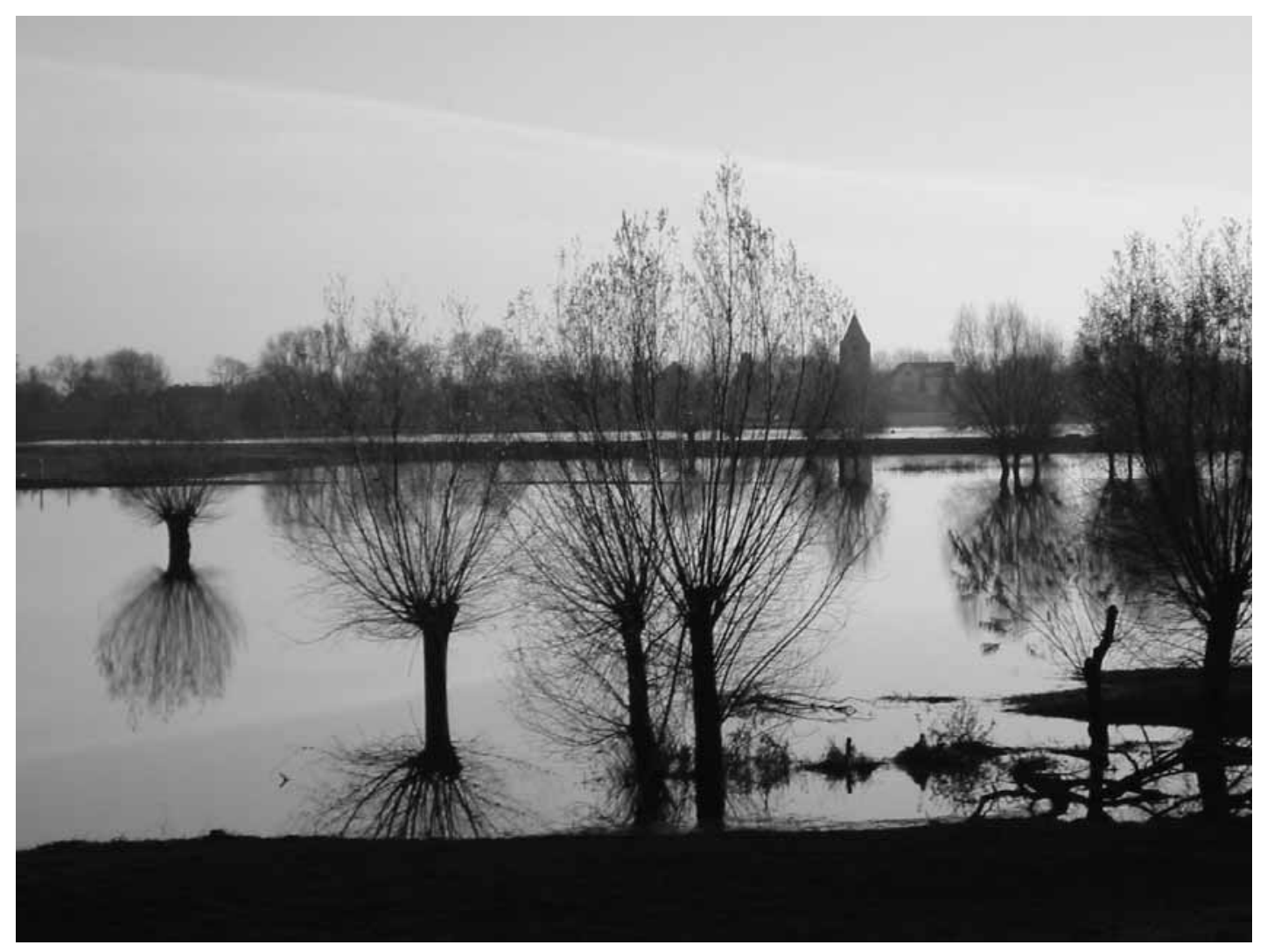

\begin{abstract}
This paper presents an analysis of two policy discourses on river and flood-hazard management. One is the established discourse 'Fighting the river' and the second is the new discourse 'Room for the river'. The paper focuses on concepts that are part of discourse in order to learn more about their role and position in scientific research. This insight is used to illustrate the main differences between the approaches to hazards and risks adopted by the natural and social sciences. Insights into these differences are important in developing an integrative approach to sustainable river and flood-risk management by collaboration between various actors. The perspectives of water managers and spatial planners are presented in order to clarify the potential role of these actors in a collaborative policy practice. Finally, the results are discussed
\end{abstract}

\footnotetext{
\# Wageningen University, Land Use Planning Group, Generaal Foulkesweg 13, 6703 BJ Wageningen, The Netherlands. E-mail: Irene.Immink@wur.nl
} 
in a broader and international context of research on hazard analysis, risk and vulnerability assessment.

Keywords: river-basin management; floods; policy arrangement; natural science; social science; flood hazard; disaster; risk assessment; vulnerability assessment

\section{Introduction}

After water levels in The Netherlands reached a near-critical level in 1995, a new discourse for managing the lower Rhine basin was introduced into debates about river management. This discourse, called 'Room for the river', introduces a new management strategy in which the river is given more room (i.e. land adjacent to the main course of the river is made available for flooding) in order to reduce the risk of flooding. This new discourse is changing the practice of river management. A discourse is a storyline that can be described as a specific ensemble of ideas and concepts which are produced and transformed in policy practices (Hajer 1995). Actors use discourses to give expression to their vision on reality and social relations with other actors during debates. So, discourses are constructed in policy domains by actors.

\section{Research objectives}

The main objective of this study is to develop an understanding of the differences between the approaches of natural and social sciences to hazard management. This understanding is necessary in defining the role of each discourse and the relation between the discourses 'Fighting the river' and 'Room for the river'. This insight offers a direction for the development of an integrative policy practice for river-basin and flood-risk management. The differences in perspectives on river and flood-risk management in each discourse and related contextual and organizational aspects of both discourses are the key issues for research. These differences are presented in Table 1. From this perspective, this study will analyse the approaches of natural and social sciences and the related frames (applications) of actions and decisions on hazard management.

Table 1. Summary of key differences between the 'Fighting the river' and 'Room for the river' discourses

\begin{tabular}{lll}
\hline Relevant issues & Established policy arrangement & $\begin{array}{l}\text { Elements of a new, collaborative policy } \\
\text { arrangement }\end{array}$ \\
\hline $\begin{array}{l}\text { Discourse } \\
\text { Context }\end{array}$ & $\begin{array}{l}\text { Fighting the river } \\
\text { National - sectoral }\end{array}$ & $\begin{array}{l}\text { Room for the river } \\
\text { Regional - integrative }\end{array}$ \\
$\begin{array}{l}\text { Main approach } \\
\text { and linked } \\
\text { action/decision } \\
\text { frame } \\
\text { (application) }\end{array}$ & $\begin{array}{l}\text { - Natural-science approach: one-hazard } \\
\text { concept }\end{array}$ & $\begin{array}{l}\text { - Integrative perspective needed: Social-science } \\
\text { approach: hazard-of-place concept }\end{array}$ \\
$\begin{array}{l}\text { Organizational } \\
\text { aspects }\end{array}$ & assessment (disciplinary orientation) & $\begin{array}{l}\text { Identification of a suitable action/decision } \\
\text { frame. Vulnerability assessment } \\
\text { (multidisciplinary orientation) }\end{array}$ \\
& $\begin{array}{l}\text { Government: Single-agency responsib.: } \\
\text { - Limited number of specialized actors } \\
\text { are responsible for managing risk }\end{array}$ & $\begin{array}{l}\text { Governance: Multiple-agency responsibilities: } \\
\text { Various (multiple) actors with different levels } \\
\text { of responsibility for managing risk }\end{array}$ \\
& $\begin{array}{l}\text { Onultiple policy domain: water management, } \\
\text { One policy domain: water }\end{array}$ & $\begin{array}{l}\text { spatial planning, environmental and nature } \\
\text { management, recreation, etc. }\end{array}$ \\
\hline
\end{tabular}




\section{Research questions}

Based on the research objectives, the following research questions have been posed:

1. What are the main approaches for hazard analysis that are adopted by the natural and social sciences, and how are the two discourses related to these approaches?

2. What action and decision frames for risk and vulnerability assessment can be distinguished, and how are these related to the main approaches for hazard analysis adopted by the natural and social sciences?

\section{Theory and methods}

The theoretical framework is based on a constructivist perspective. The methods used are qualitative methods adopted by discourse analysis and planning theory.

According to Crotty (1998) constructivists are considering that all knowledge, and therefore all meaningful reality as such, is contingent upon human practices, being constructed in and out of interaction between human beings and their world, and developed and transmitted within an essentially social context. So, a constructivist perspective identifies assumptions about the world in which humans live and work (Creswell 2003). These assumptions are varied and multiple, leading to a research focus that is orientated to the complexity of views, perspectives and opinions. Assumptions are opinions and beliefs constructed by humans as they engage with the world they are interpreting; they try to make sense of the world based on their historical and social perspectives (Crotty 1998). Thus, qualitative research with this purpose seeks to understand the contexts or settings in which humans act and in which phenomena occur. These assumptions are a starting point for the inductive generation of theory by social inquiry (Flyvbjerg 2001; Yin 2003). The strategy of this perspective is to rely on the participants' perceptions of the situations and issues being studied. So, this qualitative perspective is used to establish an understanding of varied contexts or settings in which actions and decisions by actors for river and flood-risk management are planned and taken. These qualitative data are gathered by openended interviews with participants. Contexts or settings that are studied and from which qualitative data has been collected are the subjects of a multiple-case study.

In order to juxtapose the discourse 'Room for the river' with the discourse 'Fighting against the river' scientifically, a discourse analysis has been made. Discourse analysis is a method of text analysis (Fairclough 2003; Titscher et al. 2000). The main discursive elements (i.e. the main concepts) such as 'defending by dikes', 'river basins' and 'accommodating water' are identified from policy documents in which the two discourses for river and flood-risk management are described (Ministerie van Verkeer en Waterstaat 2001a; Bouwdienst Rijkswaterstaat 2002). The origins of these concepts have been explored by a review of the literature drawn from the natural and social sciences on natural-hazard analysis, disaster studies and their applications in risk and vulnerability assessment. The results of the discourse analysis and the literature study leads to an understanding of the position of each discourse and of how both discourses are affected by natural- or social-science approaches to hazard analysis.

Planning Theory is used for the analysis of differences in views on the discourse 'Room for the river' by water managers and spatial planners. In Planning Theory, the central question is directed towards the relationship between knowledge and action, called the 'knowledge-action' nexus (Friedmann 1994). Van der Valk (1998) 
distinguished two main planning approaches: 'social engineering', an expert approach, and 'joint learning', a multiple-actor approach. These planning approaches are presented in Table 2. They are supportive for the analysis of the knowledge-action nexus of actors involved in the development of the discourse 'Room for the river' into an established policy practice. The established discourse 'Fighting the river' can be characterized by the 'social engineering' planning approach. 'Joint learning' is potentially important in organizing a new integrative policy domain.

Table 2. Planning approaches of 'Social Engineering' and 'Joint Learning' (Source: Van der Valk 1998)

\begin{tabular}{|c|c|c|}
\hline Characteristic aspect & $\begin{array}{l}\text { Social Engineering } \\
\text { (expert approach) }\end{array}$ & $\begin{array}{l}\text { Joint Learning } \\
\text { (multiple-actor approach) }\end{array}$ \\
\hline Planning subject & $\begin{array}{l}\text { One actor (hierarchical } \\
\text { perspective) }\end{array}$ & $\begin{array}{l}\text { Coalition of several actors (network } \\
\text { perspective) }\end{array}$ \\
\hline Status of knowledge & Knowledge is objective & $\begin{array}{l}\text { Knowledge is negotiated knowledge } \\
\text { by multiple actors (joint fact-finding) }\end{array}$ \\
\hline Decision-making & Goal-oriented, top-down approach & Goal-searching, bottom-up approach \\
\hline Role of expert & Central role & One of more roles \\
\hline Role of government & Central actor (government) & One of the actors (governance) \\
\hline $\begin{array}{l}\text { Steering and } \\
\text { coordination }\end{array}$ & Uni-centric & Pluri-centric \\
\hline Plan objective & $\begin{array}{l}\text { A plan is a technical execution } \\
\text { instrument }\end{array}$ & $\begin{array}{l}\text { A plan is a framework for decision- } \\
\text { making and collaboration }\end{array}$ \\
\hline $\begin{array}{l}\text { Vision on management } \\
\text { innovation }\end{array}$ & Technical - 'fine-tuning' & Institutional, reflexive \\
\hline Planning process & Successive phases & Cyclic, interactive \\
\hline Legitimating & $\begin{array}{l}\text { Common interest and } \\
\text { responsibility }\end{array}$ & Shared interest and responsibility \\
\hline
\end{tabular}

\section{Discourse and policy arrangements}

A policy domain can be described by the concept of 'policy arrangements', which refers to a stabilization of a policy domain during a particular period (Van Tatenhove, Arts and Leroy 2000). According to Van Tatenhove an established discourse has a suitable organizational (institutional) dimension which, taken as a whole, is called a policy arrangement. Three dimensions of the organization that can be distinguished are the actors involved (the coalition), the distribution of responsibilities and resources among the actors involved, and the rules of the game (see Figure 1). A coalition is a group of actors supporting a point of view that is formulated in a discourse. The distribution of responsibilities and resources provides an impression of the power of each actor involved to influence decisions in the policy domain by using resources such as knowledge and financing. The last organizational dimension, 'rules of the game', represents formal and informal agreements and rules for actors who influence the decision-making processes in policy practice. 


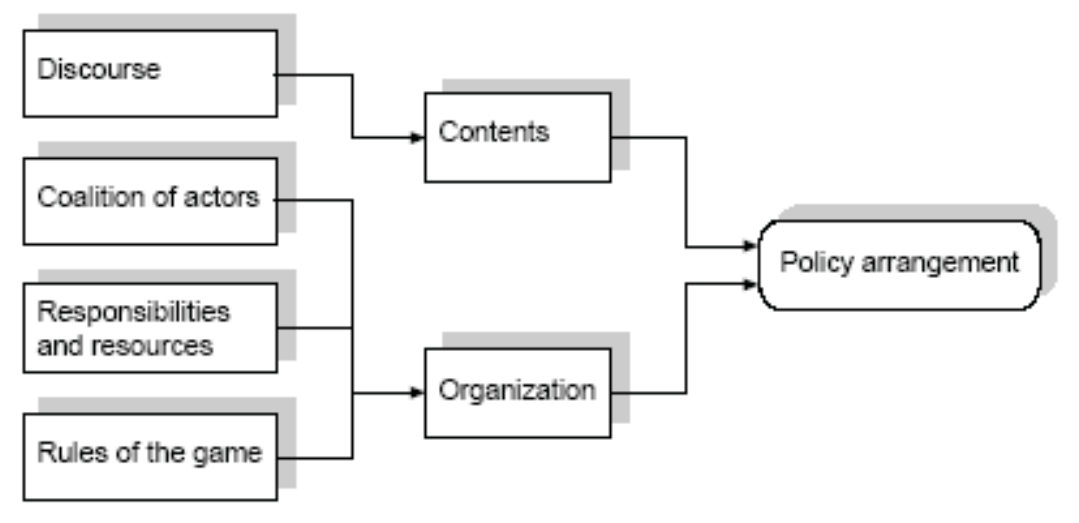

Figure 1. The concept of policy arrangements provides a relation between discourse and the organization of a policy practice (Source: Van Tatenhove, Arts and Leroy 2000)

The organization of the established discourse 'Fighting the river' can be characterized as a government practice (Wiering and Immink 2003). The discourse involves a small number of actors, principal among who are the Water Directive (Ministry of Public Works and Water Management) at the national policy level and the Water Boards at the regional policy level. The practice has a sectoral orientation and is based upon expert planning with a reactive top-down planning approach. These actors have specialist expertise, enabling them to make financial decisions on issues of water and flood-risk management.

The new discourse 'Room for the river' has begun to play a role in recent policy developments and in the establishment of new actor coalitions (Ministerie van Verkeer en Waterstaat 2004). The Ministry of Public Works and Water Management has started a participative planning process for developing new river management plans, in cooperation with various national, regional and local actors (Bouwdienst Rijkswaterstaat 2002).

Because of the transition in both the debate about and the practice of river and flood-risk management, there have been changes in the contextual and organizational structures in the policy domain for river and flood-risk management. The new discourse represents a more collaborative strategy for river basin and flood-hazard management than the 'go-alone' (or single-actor) strategy of the discourse 'Fighting the river'. Such collaborative strategy has certain contextual and organizational consequences that can be characterized, from the perspective of policy studies, as a means of governance (Van Tatenhove, Arts and Leroy 2000). Adopting a governance approach supports the involvement of a broader range of actors and stakeholders, for example, actors responsible for spatial and environmental management, for protecting landscape and nature, and for recreation. This transition process means a 'socialization' of the policy domain of river management and the possibility of establishing new actor coalitions (De Wilt, Snijders and Duijnhouwer 2000). As a consequence, a suitable action/decision frame needs to support a multidisciplinary orientation in order to establish a collaborative decision-making across a network of various actors in a governance setting. Therefore, an integrative perspective is necessary (see Table 1). 


\section{Results}

Discourse analysis and literature study offer an insight into the scientific basis of both the established discourse 'Fighting the river' and the new discourse 'Room for the river'. This insight is essential to bring them together. An understanding of the scientific basis of each discourse is necessary for the development of an integrated approach for river-basin and flood-risk management. This understanding is also useful for the development of a supporting body of knowledge, which is one of the main resources for the actors involved in an integrative policy practice.

\section{Natural-science and social-science approaches}

In the research field of natural-hazard analysis and disaster studies, two main approaches can be distinguished: the natural-science approach and the social-science approach (Sarewitz, Pielke and Keykhah 2003; White, Kates and Burton 2001). According to the literature studied, the natural-science approach is linked to applications that are based on the concept of risk assessment (Smith 2001). Social science is linked to applications that are based on the concept of vulnerability (Bankoff, Frerks and Hilhorst 2004). Figure 2 gives a contrasting overview of the two approaches provided by the natural and social sciences and their relationships towards applied science. In the following subsections, the natural- and social-science approaches and related applications are explained separately, directly followed by a description about how these analysed approaches are related to the two discourses. In the last subsection, the two discourses and their analysed approaches are brought together in order to address issues that are essential for integration.

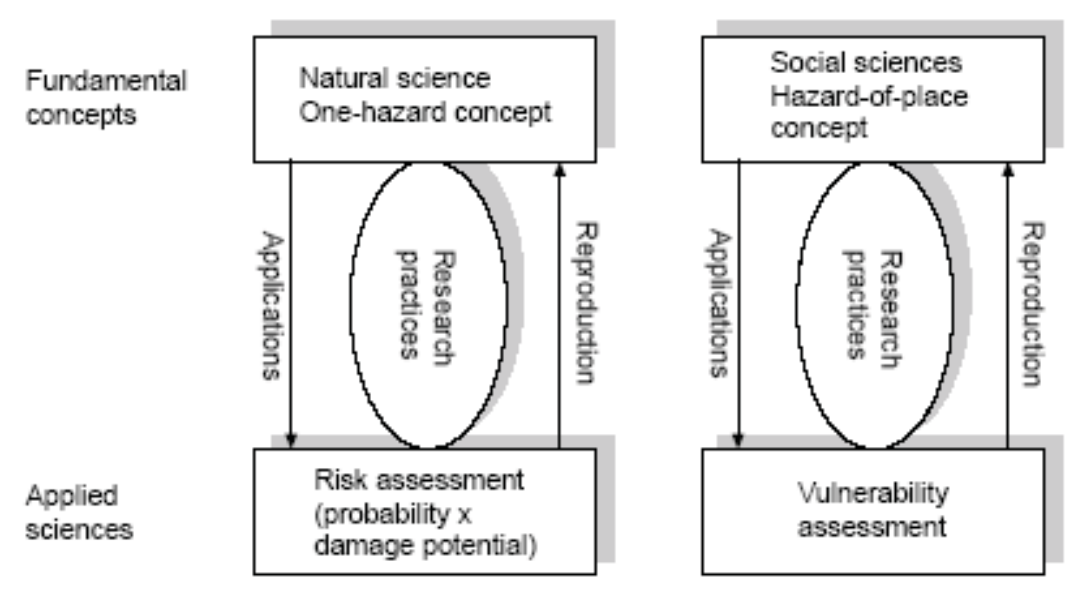

Figure 2. Organization of natural- and social-science approaches and related applications

\section{Natural-science approaches}

In the field of natural-science research on hazards and disasters, the main concept is the one-hazard approach (White, Kates and Burton 2001). This means that domain experts study several hazards separately, examples of these being earthquakes, volcanoes, landslides, tornadoes, hurricanes, wildfires, floods and droughts (Smith 2001). The central idea in this approach is that disasters are caused by natural hazardous phenomena and are beyond human control. Disasters are considered as 'acts of nature' or 'acts of God' (Wijkman and Timberlake 1984). Table 3 summarizes the main characteristics of an analysis using the natural-science approach. 
Table 3. Example characteristics of analysis by natural-science approaches (Source: Rosenhead and Mingers 2001)

\section{Characteristics of analysis by natural-science approaches}

- Problem formulation in terms of a single objective and optimization

- There are issues of data requirements, with problems of data availability and credibility

- There tends to be an assumed consensus and an isolation from political considerations

- Applications are typically orientated at the level of a single decision-maker, with abstract and context-independent expert objectives. Implementation is often by a hierarchical chain of command (top-down approach)

- People are considered passive objects

- Attempts are made to remove, or quantify, uncertainty and provide solutions to future problems

- Following a model for disaster-response planning there are phases of preparedness, response and recovery

Risk assessment is linked to natural-science approaches on hazards and disasters. It is used as an application for planning and decision-making in many sectoral (specialized) mitigation policy practices (Etkin 1999; Mileti 1999). From an analytical point of view, the concept of risk assessment describes a static, linear cause-and-effect relationship, as shown in Figure 3.

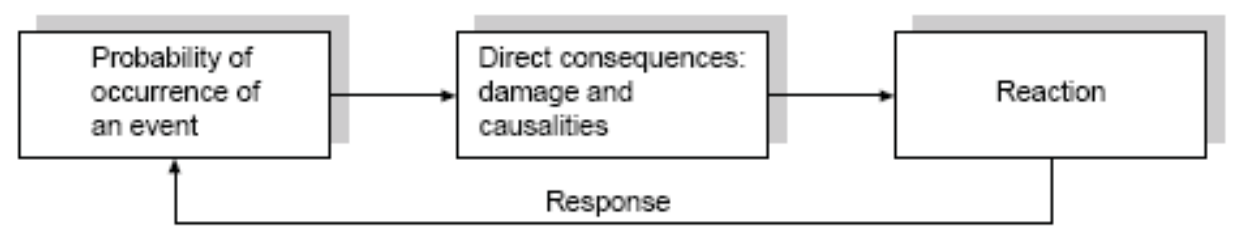

Figure 3. The concept of risk assessment

Risk assessment is an event-orientated concept that has a narrow focus on physical processes and direct exposure. It focuses on the prediction (i.e., the probability of occurrence) of a hazardous event and its direct consequences: economic damage and causalities (Cutter 2001). It relies upon quantitative, physical analysis which is orientated towards short-term planning objectives. A risk model can consider medium- and long-term issues as well, with lower levels of confidence placed on the outcomes. There is an emphasis on mitigation measures, which are based on technical and structural solutions (Weichselgartner and Obersteiner 2002). The outcome of the risk assessment of a particularly hazardous event is compared to a protection (or mitigation) level: a risk norm. Such risk norms are mostly established by expert judgment and rarely by debate and decision-making in society, but in the aftermath of a disaster, the risk norms in question are often the subject of debate. Risk assessment is a tool typically used for response management.

The discourse 'Fighting the river' has a scientific basis provided by the natural sciences. This discourse links the one-hazard concept 'defending by dikes' with the action and decision frame of flood-risk assessment. In flood-risk assessment, risk norms are used to formulate design criteria for mitigation measures, like the design criteria for a river dike. Risk assessment is an event-orientated action and decision frame because it has a focus on the prediction of peak discharges (i.e. a potential flood). The view on river management in the established discourse 'Fighting the river' 
is that the river should be controlled by building dikes to reduce the risk of flooding (Ministerie van Verkeer en Waterstaat 2001a). Offering resistance against the influences of the river is the key issue in this discourse, which reflects a practice of river management that has been a tradition for centuries in The Netherlands. The main concept is 'defending by dikes'. According to the strategy provided by this concept, a management response after flooding or critical periods is to improve the dikes, for example by increasing their height. Figure 4 shows a caricature of what dikes will look like in the future as a result of the ongoing strategy of making them higher.

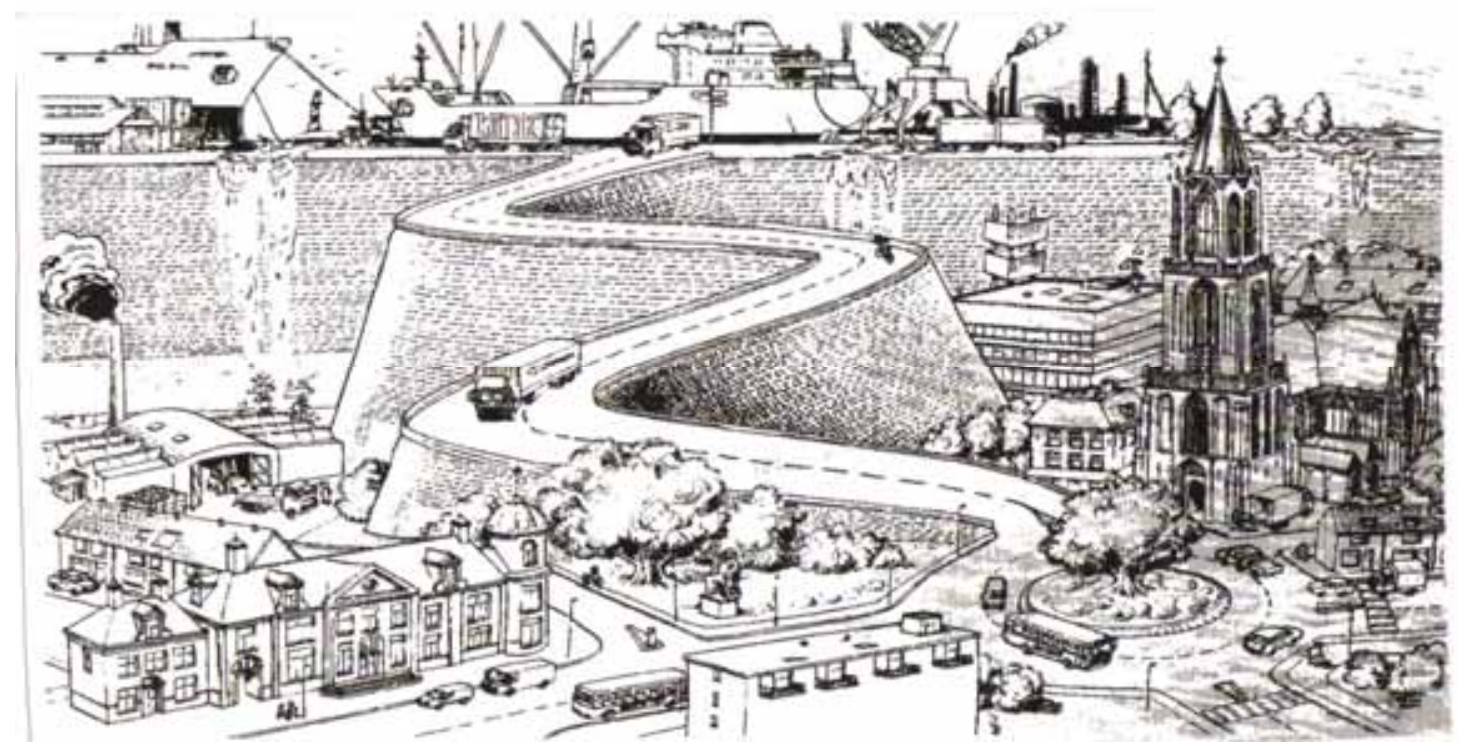

Figure 4. A caricature impression of the discourse 'Fighting the river' (Source: Ministerie van Verkeer en Waterstaat 2001b)

\section{Social-science approaches}

Social-science approaches adopt a view on relations between physical and social processes that can alter a society's level of vulnerability. It is a so-called hazard-ofplace approach, focusing on both physical and social stressors that influence hazard components in specific places (i.e. provides a context). The hazard-of-place approach recognizes that the natural environment has its own ecological and biophysical boundaries. In other words, this approach emphasizes an integrative approach to geographic convergences of water, land and air, all of which need to be taken into consideration in environmental management (Executive Resource Group 2001). The central view on causation is that reasons for disasters lie in human influences on the environment (White, Kates and Burton 2001) and that disasters are considered acts of humans (Wijkman and Timberlake 1984). Social-science approaches distinguish between 'physical trigger processes' (for example, river peak discharges, too much rain, droughts), which may be natural, and the associated disaster, which may be largely human-made. Fields of study in social-science approaches are, for example, the relationships between public policy, land use, and disasters and perception studies (Burby 1998; Comfort et al. 1999; Tobin and Montz 1997). Table 4 summarizes the main characteristics of analysis by social sciences. 
Table 4. The main characteristics of analysis by social science (Source: Rosenhead and Mingers 2001)

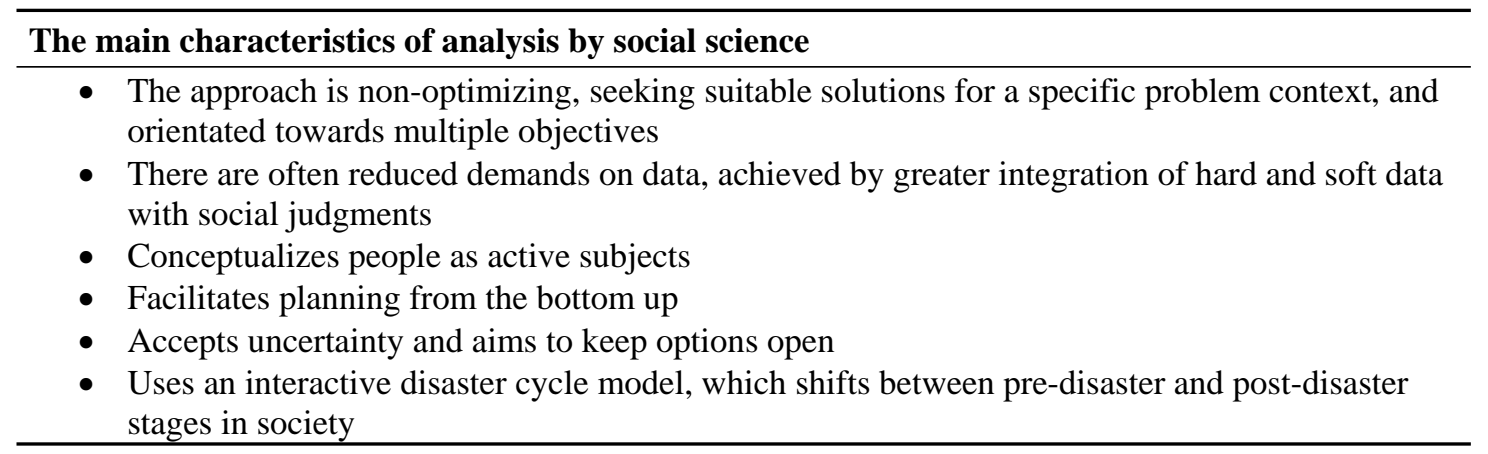

Vulnerability assessment is linked to social-science approaches to hazards and disasters (Cutter 2001; Mileti 1999; White, Kates and Burton 2001). From an analytical point of view, this concept can be described as a set of interactive, nonlinear feedback relations as is shown in Figure 6. Vulnerability assessment is a process-orientated concept, focusing on relations between hazards and contexts (Bogard 1994). Key issues are a qualitative social-science approach, cause-oriented analysis and an understanding of the complexity of reflexive relations between natural systems, human-built systems and social systems. Mitchell, Devine and Jagger (1989) have developed a contextual model of hazard, which is presented in Figure 5. They distinguish four separate but interacting hazard components: physical processes, human populations, adjustment to hazard, and net losses. The components modify each other through seven endogenous feedback relations so that a change in one or more components may set reflexive changes in the others.

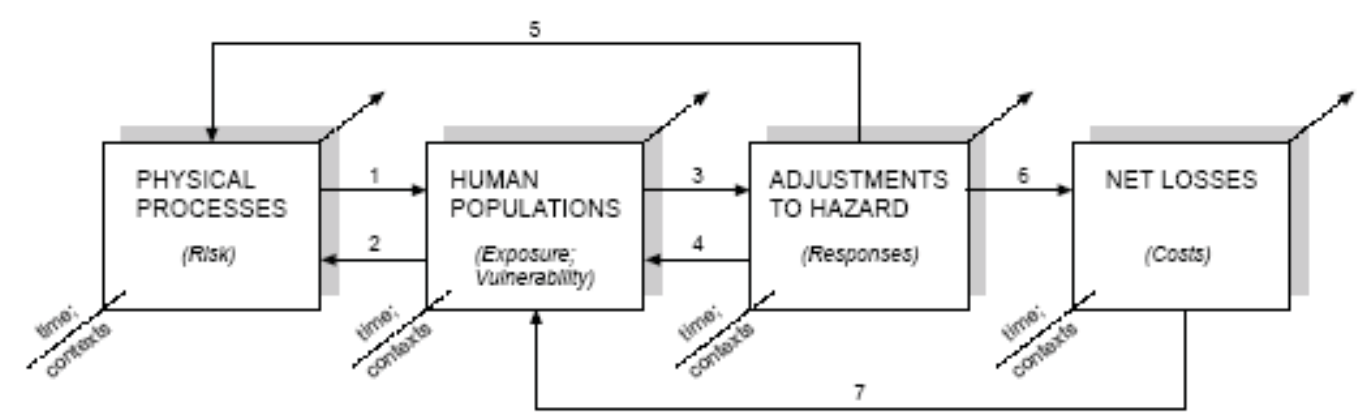

Figure 5. Example of vulnerability assessment (Source: Mitchell, Devine and Jagger 1989)

Physical processes affect human activities (link 1), but the latter can also change the former (link 2). Adjustments may modify physical processes (link 5) and human exposure or vulnerability (link 4), but they rarely eliminate all losses (link 6), and net losses are monitored by society (link 7). The hazard context includes exogenous factors that interact and modify components of hazard but are largely independent of them. Exogenous factors change in time and space (see dotted arrows in Figure 4). Examples of these factors are climate change and demographic and urbanization processes. Thus, focusing on relations between natural systems, social systems and human-built systems makes emerging aggregate patterns of vulnerability visible (Weichselgartner and Obersteiner 2002). 
The new discourse 'Room for the river' is affected by social-science approaches. The discourse is influenced by international debates on issues of sustainability, climate change and urbanization processes in river deltas. Its goals are to establish a planning strategy based upon anticipation of flooding and to prevent flooding damage (Bouwdienst Rijkswaterstaat 2002). This discourse introduces concepts such as the river-basin (or watershed) approach and 'accommodating water'. The river-basin concept has an orientation that is suitable for the 'hazard-of-place' approach, because of the focus on interrelations between several geographic convergences such as landuse patterns, groundwater and surface-water systems. Vulnerability assessment provides potential possibilities for collaborative decision-making by various actors because of its focus on issues of physical processes, human environment and social adjustments to hazards and losses. It offers a multiple goal orientation which is essential to the collaboration between various actors. For example, physical processes, like peak discharges on the river, and social adjustments to hazard, like urbanization processes in flood-prone areas, can be analysed and studied from a comprehensive perspective. The goal of the strategies of anticipation and prevention is to regulate intensive land-use forms in flood-prone areas along the river and to establish spatial measures such as water retention areas and dike relocations, so that the river has more room during critical periods. Vulnerability assessment is a framework which can help to develop knowledge about interrelations between physical and social processes, and it can guide in establishing a better understanding of the complex interactions between them. These insights are potentially important for actors being able to coordinate and make decisions within the framework of the strategies of prevention and anticipation in order to manage society's vulnerability in the face of floods. These strategies depend on the collaboration between water managers and other actors, such as the spatial-planning authorities. Figure 6 shows a caricature that illustrates the functioning of a water retention area that has a function not only for safety and water storage but for recreation as well.

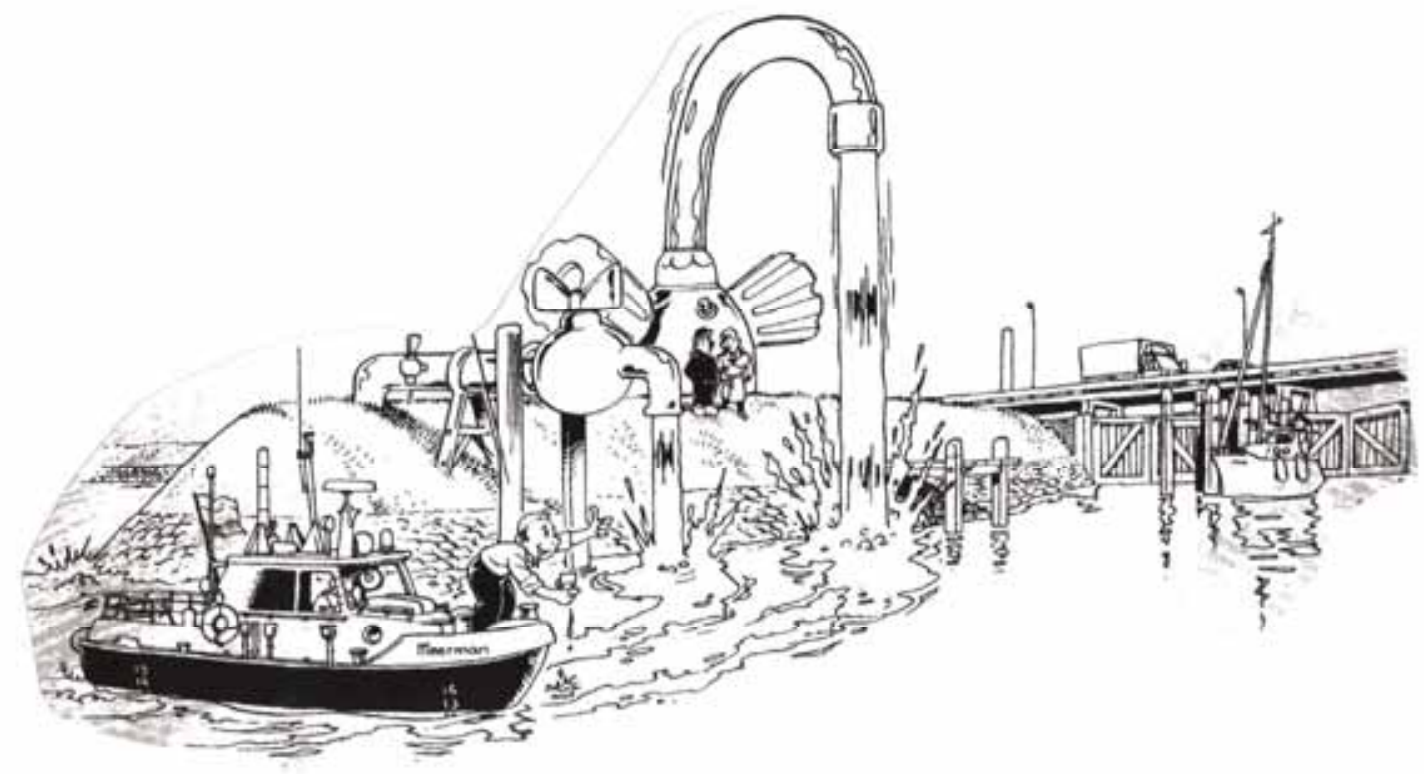

Figure 6. A caricature impression of the discourse 'Room for the river' (Source: Ministerie van Verkeer en Waterstaat 2001b) 


\section{Integration: bringing the two discourses together}

To position the role of each discourse and the relation between the two, it is important to consider the fundamentally different dimensions of natural and social sciences. According to Flyvbjerg (2001), natural and social sciences have respective strengths and weaknesses along fundamentally different dimensions. Social science is strong in reflective analysis of processes in specific contexts and in analysis of a society's values and interests. The strength of natural science lies in explanatory and predictive theories independent of the dimensions of time and place. From this perspective the relation between both discourses becomes obvious. Integrated riverbasin and flood-risk management should bring together natural- and social-science approaches by linking knowledge about hazardous events and related contexts (Mitchell, Devine and Jagger 1989). For example, the occurrence of a flood event in a sparsely populated area, which affects no one, may not be considered a disaster of the same magnitude as when a flood event occurs in a large urbanized, flood-prone area; then we speak of a disaster in terms of human suffering and deaths. However, is the disaster associated with the flood or of the fact that people are living there? This example makes clear the importance of context. The discourse 'Room for the river' has an integrative regional perspective on river-basin and flood-risk management. So, 'context' is a valuable factor in shaping the role of this new discourse, besides the focus on prediction of river peak discharges by the established discourse 'Fighting the river'. Figure 7 addresses the relation between the two discourses. The question is how an integrative policy practice for river-basin and flood-risk management must be organized. Is it an issue of the two discourses that will be integrated or is integration only a matter within the new discourse 'Room for the river'? According to the conceptual perspective of policy arrangements, integration of the two discourses should result into one established policy arrangement. And integration within the new discourse 'Room for the river' should be organized within a new policy arrangement. If that is the situation, this new policy arrangement should be considered beside the established policy arrangement of the discourse 'Fighting the river' (see Figure 7). Until now, the new discourse 'Room for the river' has not been an established policy arrangement that includes a suitable action and decision frame for the actors involved. So, the question is whether or not vulnerability assessment is a suitable action and decision frame to establish a suitable organization for an integrative policy arrangement within a form of governance. However, for both possible directions for integration, the relation between the action and decision frames of flood-risk and vulnerability assessment becomes important. It raises the issue of definition of the role of each concept, risk and vulnerability assessment, from a holistic perspective (Cardona 2004). 


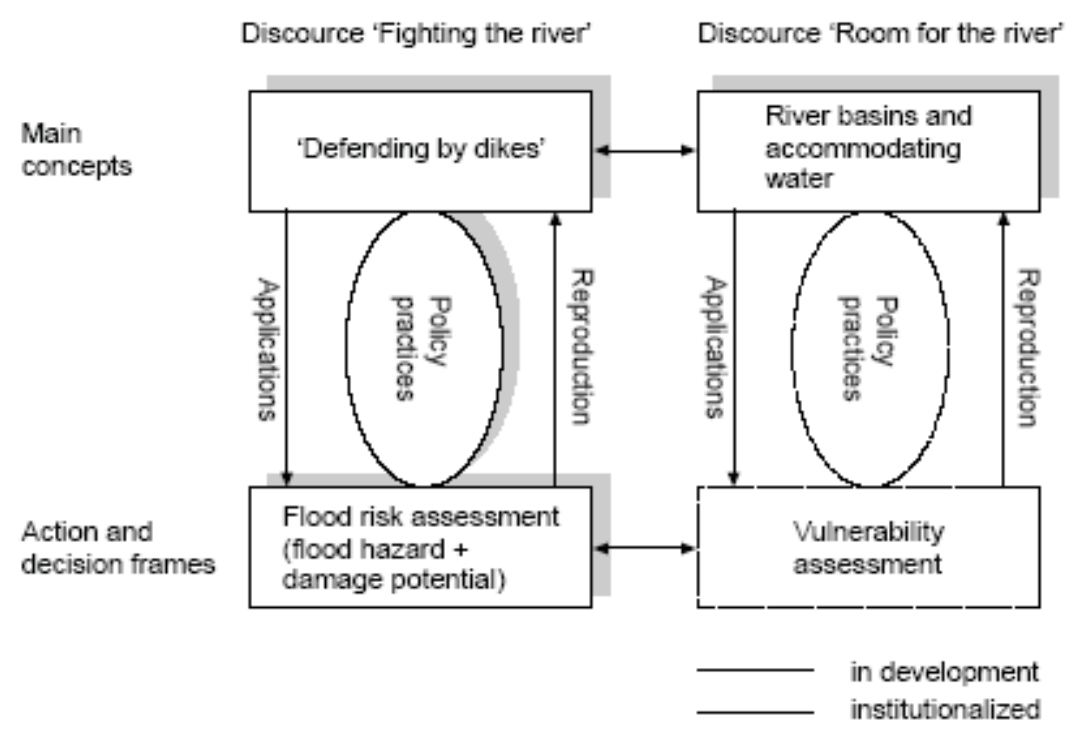

Figure 7. Discourses and linked action and decision frames

Table 5 offers an impression of differences between the 'knowledge-action' nexus of water managers and spatial planners. This table has been constructed based on information from conversations with water managers and spatial planners who are involved in developing 'Room for the river' into an established policy practice. The actors (water managers) are interested in further developing and improving prediction models to reduce the uncertainty of the probability of a peak discharge occurring on the river. The perspective of water managers on the discourse 'Room for the river' is to plan measures, such as dike relocation, that mitigate the effects of a peak discharge on the river and reduce its potential risk to grow into a flooding disaster.

Table 5. Differences between the 'knowledge-action' nexus of water managers and spatial planners

\begin{tabular}{|c|c|c|}
\hline $\begin{array}{l}\text { Characteristic aspect } \\
\text { 'knowledge-action' } \\
\text { nexus }\end{array}$ & Water managers (engineers) & Spatial planners \\
\hline Planning approach & Social Engineering & Joint Learning \\
\hline $\begin{array}{l}\text { Perspective on } \\
\text { 'Room for the river' }\end{array}$ & $\begin{array}{l}\text { Operational - 'Room for the river' } \\
\text { means spatial claims for dike } \\
\text { relocation (more room for the river } \\
\text { bed itself) }\end{array}$ & $\begin{array}{l}\text { Strategic - 'Room for the river' is a } \\
\text { guiding and structural principle for } \\
\text { spatial and landscape planning in river } \\
\text { basins }\end{array}$ \\
\hline Risk perception & Flooding risk is a norm & $\begin{array}{l}\text { Flooding risk is relative (i.e. risk is } \\
\text { placed in a context) }\end{array}$ \\
\hline Causal relations & $\begin{array}{l}\text { Cause-effect relations are } \\
\text { transparent and static }\end{array}$ & $\begin{array}{l}\text { Cause-effect relations are complex and } \\
\text { change in time and space }\end{array}$ \\
\hline View on space & $\begin{array}{l}\text { Space is quantitative - hectares, } \\
\text { volumes, cubic metres that are used } \\
\text { as input for modelling the effects of } \\
\text { planned measures }\end{array}$ & $\begin{array}{l}\text { Space is qualitative - identifying } \\
\text { region-specific processes. Developing a } \\
\text { strategic perspective on spatial } \\
\text { development }\end{array}$ \\
\hline
\end{tabular}

According to Table 5, the perspective on 'Room for the river' by spatial planners is quite different from that of the water managers. To spatial planners, water is only one of the issues in spatial planning besides other ones, such as urbanization, the 
environment, etc. In other words: 'Room for the river' is not the only spatial claim that needs to be accommodated for, but one of more spatial claims that need to be accommodated for. Spatial planners have a holistic orientation, which means that they analyse spatial phenomena and developments by using a contextual perspective, such as a landscape area. From this perspective, flooding risks are relative because their potential impact depends on the presence and characteristics of other aspects in a particular landscape, such as urban and agricultural areas. Spatial planners regard 'Room for the river' as a strategic tool, which can be used to regulate and prevent intensive land-use forms in flood-prone areas (Ministerie van VROM 2004). According to their view, water can be used as a guiding principle for spatial development.

Both perspectives on 'Room for the river' by water managers and spatial planners are essential in establishing the new discourse. The perspective of the water managers is necessary for insight into potential flooding hazards because they have resources such as knowledge about the 'behaviour' of rivers and responsibilities towards safety. The perspective of the spatial planners is necessary to establish the strategies of prevention and anticipation. Spatial planners have the resources (knowledge, responsibilities and rules) to manage spatial developments. But a shared body of knowledge as one of the main resources of the actors involved in an established policy practice needs to be further developed. For that purpose vulnerability assessment provides a useful framework.

\section{Discussion}

The discourse 'Room for the river' represents shifts in hazard and risk management that are the current key issues in the broader and international context of research on hazard analysis, risk and vulnerability assessment. Three key issues are distinguished:

- the shift from a reactive strategy towards an anticipative and preventive strategy;

- a shift from a sectoral orientation (i.e. institutions) towards an integrative regionspecific (transboundary) orientation of policy arrangements;

- a shift in the conceptualization of hazard: from a 'purely' physical and isolated event towards a broader process that is affected by both physical and social events and processes.

The shift from a reactive towards an anticipative strategy has occurred in research fields that cover a broad range of natural and technical hazard and related risk management. Pearce (2003) has analysed several Australian and American research findings which show a shift from response and recovery management to proactive, sustainable hazard mitigation. It is argued that in order for this shift to occur, it is necessary to integrate hazard management and community planning. This shift has also occurred in the European context. The EC Joint Research Centre (JRC) has presented some key issues related to floods, which are shown in Table 6.

The second shift from a sectoral towards a region-specific orientation has two dimensions that are important for integrative aspects in research and policy practices. The first dimension is the systems view. According to the EC-JRC (2002) and Linnerooth-Bayer, Löfstedt and Sjöstedt (2001), the transboundary nature of flood hazards should be taken into account. The hazard-of-place concept and the river-basin approach support such transboundary management because of their focus on interrelations between land use, groundwater and surface water (Hall et al. 2003). 
Table 6. The shift from a reactive management towards anticipative or proactive management approaches (Source: European Commission 2002)

\begin{tabular}{ll}
\hline Reactive approach & Proactive approach \\
\hline One-hazard focus & Vulnerability focus \\
Single-agency responsibilities & Multi-agency responsibilities \\
Science/engineering approach & Multidisciplinary approach \\
Planning for and communicating to communities & Planning and communication with communities \\
(top-down) & (bottom-up) \\
Narrow hazard-management approach & Broader public-safety context \\
\hline
\end{tabular}

Although a general relationship between river-basin conversion and increased flooding has been established in many regions in the world, the mix of contributory interrelations and factors seems to vary considerably from place to place. Thus, the combined complex interactions of human and natural factors may have different flood-related consequences for regions in, for example, China, Great Britain and the United States (Mitchell 2003). The second dimension that is important here is the collaboration by various actors in a bottom-up planning process. The new discourse 'Room for the river' addresses such collaboration between water managers, spatial and landscape planners, environmental managers and nature conservationists. This research paper has made a limited contribution by presenting the views of water managers and spatial planners in Table 5 and exploring further possibilities of collaboration between these actors. For the broader perspective, the potential role of environmental managers, nature protectors and agricultural managers also needs identification. Currently, the possibilities and limitations of a joint planning approach for establishing 'Room for the river' in the lower Rhine river basin are being explored (Vis, Klijn and Van Buuren 2001). The collaboration by various actors has influenced the planning and design of measures. There is a trend from single-purpose (sectoral) measures such as water supply, flood control and dams towards multiple-purpose measures. Multiple-purpose measures are affected by the multiple means of the various actors. Integrated floodplain management seeks to combine a wide range of interests, such as safety, environment, landscape, recreation, etc. (Mitchell 1999).

The third shift indicates a 'socializing' trend in the conceptualization of hazard (De Wilt, Snijders and Duijnhouwer 2000; Stefanovic 2003). The cause for this shift lies in the development of holistic, more comprehensive perspectives on interrelations between society and the physical environment. According to these perspectives, society and the physical environment are not considered separate entities. As a consequence of this, a reconsideration of the concepts of vulnerability and risk is necessary. Cardona (2004) argues: "In the same way that for many years the term risk was used to refer to what is today called hazard, currently, many references are made to the word vulnerability as it were the same thing as risk. It is important to emphasize that these are two different concepts and their definition obeys a methodological approach that facilitates the understanding and possibility of risk reduction (risk assessment) or adjustment and adaptation to hazard (vulnerability assessment)". So, it is important to consider that in the view of risk assessment, disaster is a synonym of the occurrence of a hazardous event. In the perspective of vulnerability assessment, disaster is not a synonym of hazardous natural events. The capacity for adaptation and adjustments of a community when faced with natural events is the springboard for the concept of vulnerability (Cardona 2004). According to Healy (2001) and Pellizzoni (2004) there is a decline of the effectiveness of scientific-technical concepts, such as 
risk assessment, in governance policy practices. This problem is related to the perspective on uncertainty as an underlying concept of risk and vulnerability assessment. Pellizzoni (2004) distinguished two forms of uncertainty. A 'normal' form, such as the under layer of risk assessment, where possible probabilities of events and related damage are known. The second form is a 'radical' form, such as ignorance and indeterminacy (conditions for decision-making are not well known and consequences of decisions are not well understood because of the complexity of nonlinear processes and the dependence on how actors behave). There is a crucial difference between the two forms of uncertainty. The 'normal' form assumes a neat distinction between facts and values, between scientific assessments on one side, and social and human factors on the other side. The 'radical' form of uncertainty challenges this assumption because it tries to include social and human factors in the assessments. This 'radical' form of uncertainty is important as an underlying concept for the application of vulnerability assessment in policy practices. Related to flood hazards, vulnerability assessment addresses physical events, such as the peak discharges on the river, and social adjustments, such as the societal-driven spatial developments in flood-prone areas. It can be argued that a process is needed for integrating 'factual' technical and 'value-laden' social concerns (Healy 2001). According to the EC-JRC (2002), there is a 'crisis of confidence', which means a breakdown in trust in science and in the political management of hazards and risks. Neglecting this issue is a potential pitfall for governance practices. So, the consequence is that the acceptance of any risk in a governance setting depends more on qualitative risk aspects such as risks perceptions and confidence, than on quantitative estimates of risk. The EC-JRC addresses the urgent need for integrated hazards and risk management. For this purpose, a broad and substantive dialogue between the natural and social sciences is essential. Healy (2001) illustrates this need by referring to the problem of ozone depletion: "We can understand ozone depletion to be as much a matter of the internal politics of the chemical industry and of the Parties to the Montreal Protocol as it is of stratospheric chlorine loading, polar stratospheric clouds, CFCs, HCFCs, etc. In a broader social perspective risk can be understood to result from interactions of complex collective ensembles of humans and non-humans. The generation of bodies of 'public knowledge' amalgamating technical expertise with broader societal insights, knowledge, and values will be a demanding exercise".

Without a doubt, there is a strong need to bridge the differences in perspectives, methods and contexts between natural- and social-science approaches for hazard analysis, risk and vulnerability assessment. It can be argued that collaboration between scientists in the research practices is necessary to support a substantive and fruitful dialogue between natural and social sciences. This is an essential basis for the establishment of an integrative policy practice for river-basin and flood-risk management.

\section{Acknowledgements}

I would like to thank the Departments of Civil Engineering and of Integrated Water Management and Waste Water Treatment of the Ministry of Public Works and Water Management, for the financial support for my $\mathrm{PhD}$ research. According to this paper, I would like to acknowledge the assistance of David Miller and Jack Ahern for their constructive comments on a draft of this paper; and to Gunther Tress and Bärbel Tress for their useful comments and for offering me the opportunity to publish this paper. 


\section{References}

Bankoff, G., Frerks, G. and Hilhorst, D. (eds.), 2004. Mapping vulnerability: disasters, development, and people. Earthscan Publications, London.

Bogard, W.C., 1994. Bringing social theory to hazards research: conditions and consequences of the mitigation of environmental hazards. In: Cutter, S.L. ed. Environmental risks and hazards. Prentice-Hall, Englewood Cliffs.

Bouwdienst Rijkswaterstaat, 2002. Startnotitie MER in het kader van de PKBprocedure Ruimte voor de rivier. Ministerie van Verkeer en Waterstaat, Den Haag.

Burby, R.J. (ed.) 1998. Cooperating with Nature: confronting natural hazards with land-use planning for sustainable communities. Joseph Henry Press, Washington. [http://www.nap.edu/openbook/0309063620/html]

Cardona, O.M., 2004. The need for rethinking the concepts of vulnerability and risk from a holistic perspective: a necessary review and criticism for effective risk management. In: Bankoff, G., Frerks, G. and Hilhorst, D. eds. Mapping vulnerability: disasters, development, and people. Earthscan Publications, London, 37-51.

Comfort, L., Wisner, B., Cutter, S., et al., 1999. Reframing disaster policy: the global evolution of vulnerable communities. Global Environmental Change. Part B. Environmental Hazards, 1 (1), 39-44.

Creswell, J.W., 2003. Research design: qualitative, quantitative, and mixed methods approaches. 2 edn. Sage, Thousand Oaks.

Crotty, M., 1998. foundations of social research: meaning and perspective in the research process. Sage Publications, London.

Cutter, S.L. (ed.) 2001. American hazardscapes: the regionalization of hazards and disasters. Joseph Henry Press, Washington. [http://www.nap.edu/openbook/ 0309074436/html/]

De Wilt, J.G., Snijders, H. and Duijnhouwer, F. (eds.), 2000. Over stromen: kennisen innovatieopgaven voor een waterrijk Nederland. Nationale Raad voor Landbouwkundig Onderzoek, Den Haag. NRLO-rapport no. 2000/7.

Etkin, D., 1999. Risk transference and related trends: driving forces towards more mega-disasters. Global Environmental Change. Part B. Environmental Hazards, 1 (2), 69-75.

European Commission, Joint Research Centre, 2002. NEDIES: the European repository of lessons learnt from disasters. Institute for the Protection and Security of the Citizen, Milan.

Executive Resource Group, 2001. Managing the environment: a review of best practices. Government of Ontario, Strategic Public Policy and Management Consulting, Toronto. [http://www.ene.gov.on.ca/envision/ergreport/]

Fairclough, N., 2003. Analyzing discourse: textual analysis for social research. Routledge, London.

Flyvbjerg, B., 2001. Making social science matter: why social inquiry fails and how it can count again. Cambridge University Press, Cambridge.

Friedmann, J., 1994. Two centuries of planning theory: an overview. In: Mandelbaum, S.J., Mazza, L. and Burchell, R.W. eds. Explorations in planning theory. Center for Urban Policy Research, New Brunswick.

Hajer, M.A., 1995. The politics of environmental discourse: ecological modernization and the policy process. Clarendon, Oxford. 
Hall, J.W., Meadowcroft, I.C., Sayers, P.B., et al., 2003. Integrated flood risk management in England and Wales. Natural Hazards Review, 4 (3), 126-135.

Healy, S., 2001. Risk as social process: the end of 'the age of appealing to the facts'? Journal Of Hazardous Materials, 86 (1/3), 39-53.

Linnerooth-Bayer, J., Löfstedt, R.E. and Sjöstedt, G. (eds.), 2001. Transboundary risk management. Earthscan, London. Risk, Society, and Policy Series.

Mileti, D.S., 1999. Disasters by design: a reassessment of natural hazards in the United States. Joseph Henry Press, Washington. Natural Hazards and Disasters.

Ministerie van Verkeer en Waterstaat, 2001a. Anders omgaan met water: waterbeleid in de 21ste eeuw, Den Haag. Ministerie van Verkeer en Waterstaat, Directoraat-Generaal Rijkswaterstaat. [http://www.ecologisch-herstel.nl/_files/ andersom.pdf]

Ministerie van Verkeer en Waterstaat, 2001b. Verkenningen Deltawateren. Ministerie van Verkeer en Waterstaat, Directoraat-Generaal Rijkswaterstaat, Directie Zeeland, Middelburg.

Ministerie van Verkeer en Waterstaat, 2004. Voortgangsrapportage Nationaal Bestuursakkoord Water 2003-2004. Ministery van Verkeer en Waterstaat, Den Haag.

Ministerie van VROM, 2004. Nota ruimte: ruimte voor ontwikkeling. Ministerie van Volkshuisvesting, Ruimtelijke Ordening en Milieubeheer, Den Haag. [http://www2.vrom.nl/notaruimte/download/download/NotaRuimteCompleet. pdf]

Mitchell, J.K. (ed.) 1999. Crucibles of hazard: mega-cities and disasters in transition. United Nations University Press, New York.

Mitchell, J.K., 2003. European river floods in a changing world. Risk Analysis, 23 (3), 567-574.

Mitchell, J.K., Devine, N. and Jagger, K., 1989. A contextual model of natural hazard. Geographical Review, 79 (4), 391-409.

Pearce, L., 2003. Disaster management and community planning, and public participation: how to achieve sustainable hazard mitigation. Natural Hazards, 28 (2/3), 211-228.

Pellizzoni, L., 2004. Responsibility and environmental governance. Environmental Politics, 13 (3), 541-565.

Rosenhead, J. and Mingers, J., 2001. Rational analysis for a problematic world revisited: problem structuring methods for complexity, uncertainty and conflict. 2 edn. Wiley, Chichester.

Sarewitz, D., Pielke, R. and Keykhah, M., 2003. Vulnerability and risk: some thoughts from a political and policy perspective. Risk Analysis, 23 (4), 805810.

Smith, K., 2001. Environmental hazards: assessing risk and reducing disaster. 3rd edn. Routledge, London.

Stefanovic, I.L., 2003. The contribution of philosophy to hazards assessment and decision making. Natural Hazards, 28 (2/3), 229-247.

Titscher, S., Meyer, M., Wodak, R., et al., 2000. Methods of text and discourse analysis. Sage, London.

Tobin, G.A. and Montz, B.E., 1997. Natural hazards: explanation and integration. The Guilford Press, New York.

Van der Valk, A.A.J., 1998. Het voorland van de planningtheorie. Rooilijn, 10 (31), 492-497. 
Van Tatenhove, J., Arts, B. and Leroy, P. (eds.), 2000. Political modernisation and the environment: the renewal of environmental policy arrangements. Kluwer Academic Publishers, Dordrecht. Environment \& Policy no. 24.

Vis, M., Klijn, F. and Van Buuren, M. (eds.), 2001. Living with floods: resilience strategies for flood risk management and multiple land use in the lower Rhine River basin. Netherlands Centre for River Studies NCR, Delft. NCRpublication no. 10-2001.

Weichselgartner, J. and Obersteiner, M., 2002. Knowing sufficient and applying more: challenges in hazard management. Global Environmental Change. Part B. Environmental Hazards, 4 (2/3), 73-77.

White, G.F., Kates, R.W. and Burton, I., 2001. Knowing better, losing even more: the use of knowledge in hazards management. Global Environmental Change. Part B. Environmental Hazards, 3 (3/4), 81-92.

Wiering, M. and Immink, I., 2003. Nieuwe beleidsarrangementen voor waterbeheer en ruimtelijke ordening? In: Hidding, M.C. and Van der Vlist, M. eds. Ruimte en water: planningsopgaven voor een rode delta. Sdu uitgevers, Den Haag, 183-196. Reeks Planologie no. 5.

Wijkman, A. and Timberlake, L., 1984. Natural disasters: acts of God or acts of man? International Institute for Environment and Development, London.

Yin, R.K., 2003. Case study research: design and methods. 3 edn. Sage, Thousand Oaks. Applied Social Research Methods Series no. 5. 